\title{
PASCAL PROGRAMMING
}




\section{MACMILLAN MASTER SERIES}

Banking

Basic English Law

Basic Management

Biology

British Politics

Business Communication

Business Microcomputing

Chemistry

COBOL Programming

Commerce

Computer Programming

Computers

Data Processing

Economics

Electrical Engineering

Electronics

English Grammar

English Language

English Literature

Financial Accounting

French

French 2

German
Hairdressing

Italian

Keyboarding

Marketing

Mathematics

Modern British History

Modern World History

Nutrition

Office Practice

Pascal Programming

Physics

Practical Writing

Principles of Accounts

Social Welfare

Sociology

Spanish

Spanish 2

Statistics

Statistics with your Microcomputer

Study Skills

Typewriting Skills

Word Processing 


\section{MASTERING}

\section{PASCAL PROGRAMMLING}

ERIC HUGGINS

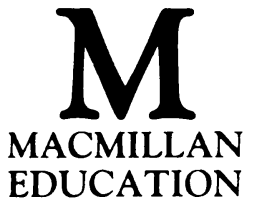


(C) Eric Huggins 1983

All rights reserved. No reproduction, copy or transmission of this publication may be made without written permission.

No paragraph of this publication may be reproduced, copied or transmitted save with written permission or in accordance with the provisions of the Copyright Act 1956 (as amended), or under the terms of any licence permitting limited copying issued by the Copyright Licensing Agency, 7 Ridgmount Street, London WC1E 7AE.

Any person who does any unauthorised act in relation to this publication may be liable to criminal prosecution and civil claims for damages.

First published 1983

Reprinted 1985, 1987

Published by

MACMILLAN EDUCATION LTD

Houndmills, Basingstoke, Hampshire RG21 2XS

and London

Companies and representatives

throughout the world

ISBN 978-0-333-32294-9 ISBN 978-1-349-17182-8 (eBook)

DOI 10.1007/978-1-349-17182-8

ISBN 978-0-333-35460-5 (export) 


\section{CONTENTS}

Preface

1 Know your computer

1.1 Introduction

1.2 Software

1

2 Introduction to programming in Pascal

3 Syntax, output format

3.1 Syntax

and FOR loops

3.2 Output format

31

3.3 The FOR loop

35

3.4 Nesting of loops

38

4 Precedence of operations

4.1 Precedence

More loops

4.2 REPEAT statements

45

4.3 IF statements

5 Applications 1:

5.1 Series

52

Mathematics

5.2 Other iterations

56

6 Types 'CHAR'. and

6.1 Introduction

60

'BOOLEAN'. Boolean

operators

6.2 Boolean operators

63

6.3 CASE operators

68

6.4 Boolean variables

70

7 Functions and procedures

7.1 Introduction

74

7.2 Procedures

7.3 Parameters

7.4 Variable parameters

80

7.5 Standard functions

89

8 External files

9 Arrays

9.1 Introduction

107

9.2 Multidimensional arrays

9.3 Syntax of arrays

9.4 Packed arrays

9.5 Strings

10 Applications 2: Sorting,

10.1 Sorting searching and merging

10.2 Sorting multidimensional arrays

10.3 Searching

10.4 Merging

10.5 Sorting of file

10.6 The LIFO stack 
12 Applications 3: Simulation 12.1 Introduction

12.2 Poisson distribution $\quad 145$

12.3 Normal distribution $\quad 149$

13 Applications 4: Graphics

12.4 A simulation problem $\quad 154$

14 Data types

14.1 Introduction

14.2 Subrange types

165

14.3 Type compatibility and

170 assignment compatibility $\quad 172$

14.4 Structured types

173

15 Records

15.1 Introduction

176

15.2 Variants

183

15.3 Linked lists

15.4 Pointer types

191

15.5 More on linked lists

15.6 A practical example of

16 Sets records and linked lists

195

16.1 Introduction

197

16.2 Compatibility of set types

202

17 Not for beginners

17.1 More about files

204

17.2 More about parameters 205

17.3 More about records 207

17.4 The GOTO statement 209

18 Applications 5: Real-time and multi-programming

19 Mainly for beginners

Appendix I The Pascal reserved

words and required identifiers

Appendix II Syntax diagrams

Appendix III Interactive input III.1 The line buffer method 248

III.2 The direct method 250

Appendix IV A subset of

the ASCII code

References

Answers to exercises

Index 


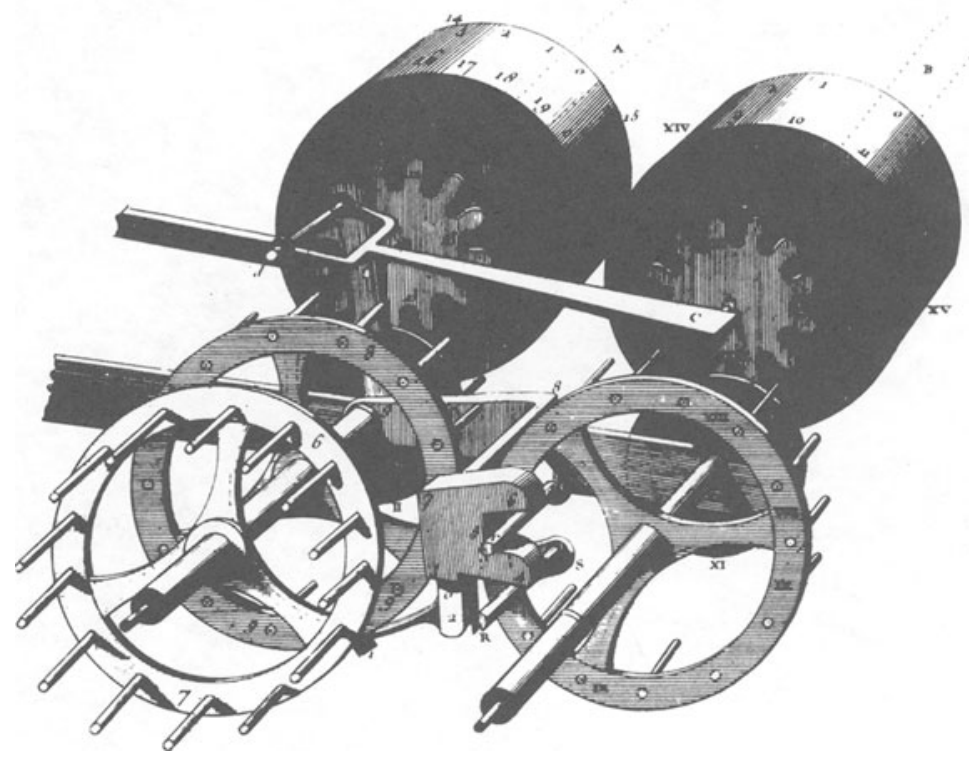

detail of part of the mechanism of the calculating machine designed and made by Blaise Pascal, then aged 19, in 1642; the drums were approximately $2 \mathrm{~cm}$ in diameter; this was the earliest computing machine on which all four arithmetical operations could be carried out; in the remaining 20 years of his life, Pascal became eminent as mathematician and philosopher; the computing language was named after him. Facsimile courtesy of the Science Museum, London 


\section{PREFACE}

The use of Pascal has been expanding rapidly during the past few years. The spectrum of users, and potential users, is wide indeed. It now ranges from those who had never previously written computer programs to those who have had considerable computing experience with other languages. Pascal is being used in science and mathematics, in business and commerce, for simulation and games, for process control in real time as well as for Wirth's primary purpose as an introduction to good programming practice. Thus, the potential readership of this book is probably drawn from a broad field with widely differing interests.

My aim has been to meet the needs both of the newcomer to computing and of the reader who has some programming experience but none of Pascal. I have tried to keep the main text virtually 'non-mathematical', though a knowledge of arithmetic and of elementary algebra is essential to any understanding of computers. An optional chapter on mathematical applications of Pascal is introduced at an early stage.

On the assumption that most readers have access, or are hoping to have access, to a small computer or a terminal, the book has been designed to allow early 'hands on' experience. Previous experience with computers is not assumed.

I have tried to structure the book in a way that will encourage selective reading according to individual needs. The Pascal language itself is covered in two separate parts. The first part (Chapters 2-9 inclusive) covers approximately the same ground as the working subset of the language, Pascal-S. To help those whose applications may be business or commercial I have included text files in this first section. After studying this first part most readers should have assimilated enough of the language to be able to write useful programs to suit their particular interests.

The remainder of the language, up to Level 0 of BS 6192:1982, is covered towards the end of the book (Chapters 14-17). Between the two parts there are optional chapters on sorting, top-down design, simulation and graphics. Chapter 18 is an optional chapter on the use of Pascal in real time. The book starts with a chapter on computing fundamentals for those new to the art and ends with a set of practical hints based on practical experience.

Each optional chapter has an opening paragraph, marked with the symbol $\square$, that guides the reader to his next step.

I have taken the view that it is counter-productive to put exercises at the end of every chapter just for the sake of having exercises. Keen pro- 
grammers will find plenty of their own problems to program. Most of the exercises either help to give a better understanding of the implementation being used or they are referred to in subsequent chapters.

The use of INPUT in interactive operation is discussed at length, since the authors of different compilers have different interpretations of what constitutes the INPUT file in interactive mode.

All the full programs (and many of the skeleton ones after 'fleshing out') have been tested either on my TRS- 80 using the Bourne/Molimerx compiler, version 5.0, or by Texas Instruments Ltd using their Microprocessor Pascal development system, version 3.0. I hope that they are thus bug-free. Since, at the time of writing, neither compiler claims complete conformity with the new British Standard and since transcription errors may have occurred, I should be most grateful to be advised of any errors or discrepancies that are discovered.

Finally I should like to express my sincere thanks to the many people who gave useful help and valid criticism during the preparation of this book. It would be invidious to mention anyone specifically since much of the most helpful criticism came from people whom I do not know even by name. I have thanked those that I do know. If the others should chance to see this book, I hope they will appreciate how much their comments on the original drafts have been taken to heart.

August 1982

ERIC HUgGins 